EISSN: $2706-7947$ ISSN: 2077- 4613

DOI: 10.36632/mejas/2021.11.1.21

Journal homepage: www.curresweb.com

Pages: 277-292

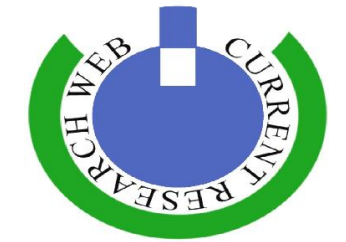

\title{
Effect of some Bread Improvers on Staling in Flat Bread
}

\author{
Amany M. Sakr \\ Bread and Pastry Research Department, Food Technology Research Institute, Agricultural Research \\ Centre, Giza- Egypt
}

\author{
Received: 10 December $2020 \quad$ Accepted: 05 March $2021 \quad$ Published: 15 March 2021
}

\begin{abstract}
Emulsifiers, hydrocolloids and enzymes are used as an anti-staling agent in bakery products, providing increasing of their shelf life, which is especially interesting for industry. The objective of this study was to evaluate the effects of the emulsifier (monoglyceride), hydrocolloids (xanthan and guar gum) and of different $\alpha$-amylases on the quality of flat bread during storage. The results showed that the maltogenic and fungi $\alpha$-amylase turned out to be an ideal anti-staling enzyme in flat bread. Also, the addition of gums (guar and xanthan) caused a slight decrease in the firmness values of the flat bread as well as, firmness was found to be increasing with the increasing level of monoglyceride in flat bread. The moisture continued to decrease, but with different additives, the decrease continued with slower rate. Finally, bread containing a mixture of xanthan, maltogenic $\alpha$-amylase, and monoglyceride maintained superior texture characteristics over the storage period while a mixture of guar, maltogenic $\alpha$-amylase, and monoglyceride was less effective over the same period.
\end{abstract}

Keywords: emulsifier, hydrocolloids, Bread, quality, storage

\section{Introduction}

Bread is a food product of great importance for consumers. It is very popular and consumed every day in all countries. Flat bread has different characteristics compared with pan bread; it has lower specific volumes; the leavened flat breads are made with a shorter fermentation period; baked with a higher baking temperature and shorter baking times. Flat breads are usually round with varying diameters and thicknesses. The crust is very thin and has a higher crust: crumb ratio (Pahwa et al., 2016). Arabic (pita) and balady bread is considered two-layered flat breads (Gocmen et al., 2009). (Aleid et al., 2015) suggested that since Arabic bread has large surface area and is baked at higher temperatures and short time than white pan bread. These differences result in substantial changes in the bread characteristics and result in faster stalling. The limited shelf life of Arabic bread due to mold growth and bread staling (firmness) results in some significant economic losses.

Staling is a textural deterioration phenomenon that also limits shelf-life of bread generally manifested by an increase in crumb firmness followed by flavor and aroma deterioration (Palacios et al., 2004 \& Al-Mahsaneh et al., 2018).Staling in flatbread results intohardness, crumbliness, loss in flavor, moisture, and other sensory qualities (Ghodke and Ananthanarayan 2007). The mechanism responsible for bread staling has been continuously reviewed. It is a complicated system where the starch retrogradation is included; however, numerous elements remain unclear (Rojas et al., 2001). The strategies for decreasing staling of baked products include the use of various enzymes, hydrocolloids, and emulsifiers (Rojas et al., 2001\&Rosell et al., 2001).

Several additives can be used to improve dough properties, bread quality and decrease stalling rate (Benejam et al., 2009). Hydrocolloids are widely used as additives in the foodindustry, because of their high-water retention capacity (Guarda et al., 2004). Water-soluble polysaccharides or hydrocolloid (gums) are used for various applications as dietary fiber, packaging films, texture improver, thickeners, gelling agents, stabilizers, emulsifiers, and coating agents (Salehi and Kashaninejad, 2014 \& Salehi et

Corresponding Author: Amany M. Sakr, Bread and Pastry Research Department, Food Technology Research Institute, Agricultural Research Centre, Giza, Egypt 
al., 2014).The utilization of hydrocolloids as anti-staling agents was recently reported by Salehi (2020) as they revealed a softening effect of with locus bean, xanthan gum and alginate hydrocolloids.

Enzymes also play a crucial role in baking technology. Different enzymes are currently added to the bread making process for improving dough handling, fresh bread quality, and also the shelf life. The enzymes most often used in bread making are the $\alpha$-amylases from different origins (cereal, fungal and microbial) although they have different properties. $\alpha$-amylases are introduced to reduce the firming rate since 1959 (Zobel and Senti, 1959).he effects related to the use of $\alpha$-amylases are a rise in the bread volume, an improvement of crumbgrain, crust and crumb color, and a contribution to theflavor development (Tebben et al., 2018). The amount of enzyme required depends on the flour, the bread making process and the desired softness. The action of amylases on bread texture has been associated with the production of low molecular weight dextrins that interfere with the ability of amylopectin retrogradation and interfere with protein-starch interactions during storage (Rojas et al., 2001).

Effective emulsifiers retard staling of bread by influencing the firming rate instead of simply reducing the initial hardness of bread. The interactions between emulsifiers and starch and/or protein are thought to be the reason for anti-staling effects (Gray andBemiller, 2003).However, this may not be the only reason for the anti-staling effects of emulsifiers, as emulsifiers can complex with amylopectin as well, although at a lower level, to reduce amylase -amylopectin network formation (Ai et al., 2018). Tang and Copeland (2007) suggested that monoglycerides form complexes of aggregated structure with amylose to decrease hardness caused by amylase retrogradation and amylose complexes with lipids and other components.

Generally, emulsifiers like (DATA ESTERS, DATEM), sodium stearoyl-2-lactylate and monoacylglycerols can delay retrogradation by either its interaction with the amylose and amylopectin or binding with water, making it unavailable to participate in gel formation (Kohajdovaz et al., 2009). Al-Eid (2000) reported that since Arabic bread is produced from formulas and processing techniques that are different from those used in the production of white pan bread. It is wrong to recommend the same types of bread improvers for both pan bread produce and Arabic bread to produce similar quality.

The objectives of this research were to investigate the effect of different flat bread improvers (percent and combinations) to improve the quality parameters of flat bread and reduce stalling.

\section{Materials and Methods}

Commercial wheat flour (72\%), salt, sugar and yeast were purchased from the local market in Giza. A maltogenic $\alpha$-amylase, a conventional $\alpha$-amylase, a fungi $\alpha$-amylase, guar gum, xanthan and monoglyceride were received from Chemotec International $\left(6^{\text {th }}\right.$ October City, Egypt $)$. The maltogenic $\alpha-$ amylase (MAX-LIFE P100) the conventional $\alpha$-amylase. The fungi $\alpha$-amylase (GRIDAMYL A $140000)$. The enzymes are referred to as maltogenic $\alpha$-amylase, conventional $\alpha$-amylase, and fungi $\alpha-$ amylase, respectively.

\subsection{Preparation of flat bread}

Two experiments were conducted, at the first experiment one additive, each with three concentrations was used, and the best concentrations were chosen for experiment two. In the second experiment, combined additives were used. The two experimental of bread were produced at Baking and pasta in Food Technology Research Institute. It was worth mentioning that 28 bread groups were produced. The straight dough method for bread production was described in AACC, (2000) and modified with as follow: wheat flour $72 \%(1 \mathrm{Kg})$ was mixed with salt $(1 \%)$, sugar $(1 \%)$, and yeast $(1 \%)$. Enzymes as $\alpha$-amylase (conventional, fungi, and maltogenic), hydrocolloids (xanthan and guar gum), and emulsifier as monoglyceride (EM) were added separately at level low $0.0125 \%$; medium $0.0250 \%$, and high $0.0500 \%$ to the above mixture water was added as needed. After mixing the ingredients, dough was allowed to ferment at room temperature $28 \pm 2^{\circ} \mathrm{C}$ and relation humidity of $76 \%$ for $20 \mathrm{~min}$. The preliminary fermented dough was divided into $100 \mathrm{~g}$ pieces and molded mechanically. Each piece was put to proof for one hour in a fermentation cabinet, at $37^{\circ} \mathrm{C}$ and $\mathrm{RH}(75 \%)$, and then baked at $300^{\circ} \mathrm{C}$. Meanwhile, the control flat bread was prepared from wheat flour $72 \%$ extraction without any addition or any treatments. The loaves were allowed to cool before evaluation and stored in plastic bags at $20 \pm$ $2^{\circ} \mathrm{C}$ for 6 days for shelf-life evaluation. Sensory evaluation and determination of water activity was performed. 


\subsection{Texture Profile Analysis (TPA)}

Texture Profile Analysis (TPA) was carried out by using Brookfield CT3 instrument (Brookfield Engineering Laboratories, Inc., MA 02346-1031, USA) according to the method outlined in the AACC (2010) which was modified for use with flat bread by using a small-scale holder TA-JPA fixture for punching through bread samples with maximum $12.7 \mathrm{~mm}$ diameter probe. Prior to testing, bread loaves were cut carefully into four quarters and each one was used at one of the experimental days ( 0 to 6 days) while the remaining quarter(s) were kept in polyethylene bags for further days test. Penetration was applied at two points of each bread quarter avoiding non-representative areas. The following test settings were used:

Target $=8.0 \mathrm{~mm}$, Trigger load $=1.50 \mathrm{~N}$, Test speed $=2.00 \mathrm{~mm} / \mathrm{s}$, Return Speed $=2.00 \mathrm{~mm} / \mathrm{s}$ and \# of Cycles $=2$.

The following TPA characteristics were determined: firmness (average of two cycles), and gumminess as described in the operating instruction manual.

\subsection{Determination of water activity and moisture loss}

Water activity (aw) was measured with a rotronic Hygro Lab EA10-SCS (Switzerland) aw meter. The measurements were performed in triplicate. Moisture content for both fresh and stored loaves was determined according to the AOAC, (2002). Triplicate samples were analyzed for each bread loaf. Moisture loss was calculated as: $\left(\left(\mathrm{M}_{0}-\mathrm{M}\right) / \mathrm{M}_{0}\right) \times 100$, where $\mathrm{M}_{0}$ is moisture of fresh bread, $\mathrm{M}$ is moisture of bread after storage.

\subsection{Sensory evaluation of flat bread}

Fresh bread loaves and those stored under the different tested temperatures for different days were subjected to sensory evaluation by a panel of 10 research staff members of Bread and Pasta Dept. at the Food Technology Research Institute, Agricultural Research Center, Giza-Egypt to evaluate the bread attributes (aroma, taste, texture, color, separation of layers, tear and overall acceptability). Each panelist was asked to rate their evaluation on a 10-points hedonic scale ranging from 1 for "extremely dislike" to 10 for "extremely like" according to the method of Larmond (1982).

\subsection{Statistical analysis}

The analytical data were analyzed using SPSS 16.0 software. Means and standard deviations were determined using descriptive statistics. Comparisons between samples were determined using analysis of one-way variance (ANOVA) and multiple range tests followed by Duncan test. Statistical significance was defined at $\mathrm{P} \leq 0.05$ according to Steel and Torrie, (1980).

\section{Results and Discussion}

\subsection{Effect of the firmness on flat bread during storage period}

The effect of various additives incorporated at different levels in flat bread dough on the firmness of flat bread stored at room temperature $18-20 \pm 2{ }^{\circ} \mathrm{C}$ is shown in Table (1).

From the results, it could be noticed that the addition of $\alpha$-amylase, in general reduced firmness and firming rate slightly compared with control bread. Firmness in flat bread was decreased linearly from 22.19 for control bread to $21.45(\mathrm{~N})$ with the addition of different concentrations of different $\alpha$-amylases at zero time except maltogenic $\alpha$-amylase. Hug-Iten et al. (2003) reported that bread baked with the maltogenic $\alpha$-amylase showed a higher initial firmness and a lower firming rate than control bread. In contrast, Lent and Grant (2001) found that the addition of fungal $\alpha$-amylase reduced staling of bread. However, all these findings are for non-flat bread; Koochei et al. (2009) results indicated that the addition of fungal a-amylase alone had a small effect on the tensile force of flat bread. The results follow the same trend after storage for different time periods.

At zero time, it can be observed that the addition of gums (guar and xanthan) caused a slight decrease in the firmness values of the flatbread. The decrease in the firmness values upon the addition of gums can be explained, as reported by Patil and Arya (2016) to be due to the highcapacity of guar gum and xanthan gum to absorb and retain more water in the dough during baking. Bread containing low concentration of guar showed the highest hardness increase after $24 \mathrm{~h}$ of storage, but lower than control sample. Results agree with Arozarena et al., (2001) who reported that using the hydrocolloids 
Table 1: Effect of additives on firmness $(\mathrm{N})$ of flat bread after different storage period

\begin{tabular}{|c|c|c|c|c|c|c|c|}
\hline Treatment & O hour & 24 hours & 48 hours & 72 hours & 96 hours & 120 hours & 144 hours \\
\hline Control & $22.19 \pm 0.06$ & $31.10 \pm 0.06$ & $46.46 \pm 0.06$ & $69.48 \pm 0.02$ & $82.67 \pm 0.02$ & + & + \\
\hline \multicolumn{8}{|c|}{$\alpha$-Amylase } \\
\hline Conventional (Low) & $21.64 \pm 0.03^{b}$ & $26.42 \pm 0.03^{\mathrm{e}}$ & $30.92 \pm 0.05^{\mathrm{a}}$ & $35.90 \pm 0.06^{\mathrm{a}}$ & $38.41 \pm 0.05^{\mathrm{b}}$ & $45.80 \pm 0.03^{\mathrm{a}}$ & + \\
\hline Conventional (Medium) & $21.54 \pm 0.03^{b}$ & $26.58 \pm 0.15^{\mathrm{d}}$ & $30.73 \pm 0.03^{\mathrm{c}}$ & $35.35 \pm 0.02^{\mathrm{ab}}$ & $37.40 \pm 0.05^{\mathrm{c}}$ & $44.79 \pm 0.03^{b}$ & + \\
\hline Conventional (High) & $21.50 \pm 0.06^{\mathrm{b}}$ & $26.12 \pm 0.06^{f}$ & $30.62 \pm 0.03^{\mathrm{d}}$ & $34.52 \pm 0.04^{\mathrm{bc}}$ & $36.35 \pm 0.55^{\mathrm{c}}$ & $45.78 \pm 0.03^{\mathrm{a}}$ & + \\
\hline Fungi (Low) & $21.77 \pm 0.03^{b}$ & $27.48 \pm 0.06^{\mathrm{a}}$ & $30.83 \pm 0.05^{b}$ & $34.53 \pm 0.08^{\mathrm{bc}}$ & $38.40 \pm 0.05^{\mathrm{b}}$ & $43.82 \pm 0.03^{b}$ & + \\
\hline Fungi (Medium) & $21.52 \pm 0.03^{\mathrm{b}}$ & $27.18 \pm 0.06^{\mathrm{b}}$ & $30.67 \pm 0.03^{\mathrm{cd}}$ & $34.47 \pm 0.02^{\mathrm{bc}}$ & $38.13 \pm 0.06^{\mathrm{b}}$ & $42.76 \pm 0.02^{\mathrm{b}}$ & + \\
\hline Fungi (High) & $21.45 \pm 0.23^{b}$ & $27.03 \pm 0.08^{\mathrm{c}}$ & $30.64 \pm 0.03^{\mathrm{d}}$ & $34.35 \pm 0.02^{\mathrm{bc}}$ & $37.18 \pm 0.02^{\mathrm{c}}$ & $42.23 \pm 0.03^{\mathrm{d}}$ & + \\
\hline Maltogenic (Low) & $22.81 \pm 0.03^{\mathrm{a}}$ & $27.58 \pm 0.15^{\mathrm{a}}$ & $30.80 \pm 0.05^{\mathrm{b}}$ & $35.39 \pm 0.06^{\mathrm{ab}}$ & $39.40 \pm 0.05^{\mathrm{a}}$ & $45.80 \pm 0.03^{\mathrm{a}}$ & + \\
\hline Maltogenic (Medium) & $22.58 \pm 0.01^{\mathrm{a}}$ & $27.20 \pm 0.06^{\mathrm{b}}$ & $30.22 \pm 0.03^{\mathrm{d}}$ & $35.35 \pm 0.02^{\mathrm{ab}}$ & $38.35 \pm 0.05^{\mathrm{b}}$ & $42.82 \pm 0.03^{b}$ & + \\
\hline Maltogenic (High) & $22.52 \pm 0.05^{\mathrm{a}}$ & $27.12 \pm 0.03^{\mathrm{bc}}$ & $29.90 \pm 0.03^{\mathrm{e}}$ & $34.40 \pm 0.04^{\mathrm{bc}}$ & $37.47 \pm 0.55^{\mathrm{c}}$ & $42.52 \pm 0.03^{c}$ & + \\
\hline \multicolumn{8}{|c|}{ Gums } \\
\hline Xanthan (Low) & $21.41 \pm 0.02^{\mathrm{a}}$ & $28.08 \pm 0.06^{\mathrm{c}}$ & $33.26 \pm 0.06^{\mathrm{c}}$ & $36.94 \pm 0.06^{\mathrm{d}}$ & $43.18 \pm 0.12^{\mathrm{d}}$ & $52.86 \pm 0.10^{\mathrm{a}}$ & + \\
\hline Xanthan (Medium) & $21.22 \pm 0.03^{\mathrm{bc}}$ & $27.92 \pm 0.02^{\mathrm{d}}$ & $32.23 \pm 0.02^{\mathrm{d}}$ & $36.55 \pm 0.03^{\mathrm{e}}$ & $42.72 \pm 0.03^{\mathrm{d}}$ & $50.78 \pm 0.02^{\mathrm{b}}$ & + \\
\hline Xanthan (High) & $21.27 \pm 0.06^{\mathrm{b}}$ & $27.85 \pm 0.09^{d}$ & $32.17 \pm 0.07^{\mathrm{de}}$ & $36.51 \pm 0.05^{\mathrm{e}}$ & $42.66 \pm 0.25^{\mathrm{d}}$ & $50.75 \pm 0.17^{\mathrm{b}}$ & + \\
\hline Guar Gum (Low) & $21.44 \pm 0.03^{\mathrm{a}}$ & $29.17 \pm 0.02^{\mathrm{a}}$ & $40.74 \pm 0.03^{\mathrm{a}}$ & $50.52 \pm 0.02^{\mathrm{a}}$ & $67.38 \pm 0.02^{\mathrm{a}}$ & + & + \\
\hline Guar Gum (Medium) & $21.23 \pm 0.03^{\mathrm{bc}}$ & $28.25 \pm 0.04^{\mathrm{b}}$ & $39.07 \pm 0.12^{\mathrm{b}}$ & $43.15 \pm 0.04^{\mathrm{b}}$ & $60.13 \pm 0.02^{\mathrm{b}}$ & + & + \\
\hline Guar Gum (High) & $21.19 \pm 0.01^{\mathrm{c}}$ & $28.00 \pm 0.17^{\mathrm{cd}}$ & $32.08 \pm 0.12^{\mathrm{e}}$ & $40.18 \pm 0.07^{\mathrm{c}}$ & $54.12 \pm 1.06^{\mathrm{c}}$ & + & + \\
\hline \multicolumn{8}{|c|}{ Emulsifier } \\
\hline Monoglyceride(Low) & $25.14 \pm 0.05^{\mathrm{a}}$ & $29.17 \pm 0.02^{\mathrm{a}}$ & $32.02 \pm 0.02^{\mathrm{a}}$ & $36.60 \pm 0.29^{\mathrm{a}}$ & $41.86 \pm 0.55^{\mathrm{a}}$ & $45.66 \pm 0.05^{\mathrm{a}}$ & $50.75 \pm 0.17^{\mathrm{a}}$ \\
\hline Monoglyceride (Medium) & $24.14 \pm 0.01^{\mathrm{b}}$ & $27.85 \pm 0.09^{\mathrm{b}}$ & $31.02 \pm 0.04^{\mathrm{b}}$ & $35.31 \pm 0.01^{\mathrm{b}}$ & $39.50 \pm 0.05^{\mathrm{b}}$ & $41.11 \pm 0.01^{\mathrm{b}}$ & $45.66 \pm 0.05^{\mathrm{b}}$ \\
\hline Monoglyceride (High) & $23.14 \pm 0.03^{\mathrm{c}}$ & $27.03 \pm 0.08^{c}$ & $30.02 \pm 0.05^{\mathrm{c}}$ & $33.35 \pm 0.01^{\mathrm{c}}$ & $36.56 \pm 0.05^{\mathrm{c}}$ & $40.11 \pm 0.01^{\mathrm{c}}$ & $44.66 \pm 0.05^{\mathrm{c}}$ \\
\hline
\end{tabular}

$(+)$ Mold grew on the external surface of bread

Values in the same column followed by different letters differ significantly $(\mathrm{p}<0.05)$. 
pectin and xanthan gum were able to control bread firming up to 5-6 d. After storage, hardness increase followed the same trend, with xanthan having a greater effect than guar gum which agrees with previous observations of Guarda et al., 2004.

In addition, firmness was found to be decreasing with the increasing level of monoglyceride in bread. These results were confirmed with work by Arozarena et al., (2001) who reported that the addition of monoacylglycerol (MAG) andsodium stearoyllactylate (SSL) delayed firming up to 7 days. Azizi et al. (2003) studied the effect of emulsifiers on dough rheological characteristics and quality of flat bread, and found that addition of surfactants delayed the staling rate of bread Kohajdová et al., (2009)explained the delay in retrogradation in presence of monoglyceride by either its interaction with the amylose and amylopectin or binding with water, making it unavailable to participate in gel formation. The results follow the same trend after storage for different time periods.

\subsection{Effect of additives on water activity of flatbread after different storage periods}

In the context of shelf life stability of control and bread with different additives, water activity $\left(a_{w}\right)$ measurements were conducted over an extended period of storage (Table 2). Substantial changes in this parameter do not occur during the first $24 \mathrm{~h}$ of storage. Upon storage for 72 hours, a significant decrease in water activity was observed for bread with monoglyceride. But after 120 hours, control and bread with guar gum were spoiled, while bread with different amylase and xanthan did not. There was no significant difference in $a_{w}$ between these samples. Bread with monoglyceride showed the lowest $a_{w}$. A significant difference in $\mathrm{a}_{\mathrm{w}}$ between control and bread samples, collected from several places in Egypt, were observed by Abd-El-Khalek et al. (2019). There was also a decrease in $\mathrm{a}_{\mathrm{w}}$ for all samples during storage. According to Nielsen (2010), the less the water activity value, the fewer chemical reactions, and microbial growth that cause decomposition. However, Sidhu et al. (1997) noticed a significant decrease was found in the water activity values during storage of Arabic flat bread. They suggested that the free water present in the freshly baked Arabic flat bread, which gave higher water activity values, was probably bound to the hydrophilic constituents (e.g. starch) of the Arabic flat bread during storage.

\subsection{Effect of additives on moisture loss of flat bread after different storage period}

Table (3) showed that moisture loss of flatbread after different storage period and the results showed that the bread moisture decreased sharply with time. The freshly baked bread contained about $40 \%$ moisture. However, during the first 24 hours the moisture dropped by $1.97 \%$ for control sample but for amylase the decrease was $0.69 \%, 0.54 \%$ for xanthan and $0.63 \%$ for monoglyceride. With additional storage time, the moisture continued to decrease, but with different additives, the decrease continued with slower rate $(3.8 \%$ for amylase, $2.14 \%$ for guar gum and $3.69 \%$ for monoglyceride compared with $7.68 \%$ for control after 96 hour of storage). These results agree with data presented by Kaltsa et al. (2013), Azanza et al. (2016) \&Abd-El-Khalek et al. (2019).

Guarda et al. (2004) \& Ai et al. (2018) suggested that the hydrocolloids affect the retrogradation level by limiting both the diffusion and the loss of water from bread crumb. In addition, other possible mechanism for explaining the anti-staling effect is that the stabilizing effects of the hydrocolloids on starch retrogradation result from the interactions of them cooperatively with water as well as with starch chains in the mixture, therefore the water content and its mobility have strong participation in this process (Lee et al., 2002)

Gavilighi et al. (2006) reported that the control sample showed the greatest differences and highest staling in all days. A descending order in staling, Guar gum $>$ Xanthan $>\mathrm{CMC}>$ locust bean was observed for retarding the staling rate of different breads. These differences between treatments were because of properties of hydrocolloids. These materials compete with starch for water and caused to reduction water adsorption.

Kaltsa et al. (2013) reported that the control sample showed the greatest differences and highest staling, while samples with DATEM showed lower moisture loss. Azanza et al. (2016) studied the addition of monoacylglycerol at $0.25 \%$ in Pandesal with pectin and antimicrobials, they reported significant increase in the moisture content of freshly-baked breads along with delayed staling. 
Middle East J. Appl. Sci., 11(1): 277-292, 2021

EISSN: $2706-7947$ ISSN: 2077- 4613

Table 2: Effect of additives on water activity of flatbread during storage period

\begin{tabular}{|c|c|c|c|c|c|c|c|}
\hline Treatment & O hour & 24 hours & 48 hours & 72 hours & 96 hours & 120 hours & 144 hours \\
\hline Control & $0.892 \pm 0.002$ & $0.883 \pm 0.003$ & $0.883 \pm 0.002$ & $0.882 \pm 0.003$ & $0.877 \pm 0.002$ & + & + \\
\hline \multicolumn{8}{|c|}{$\alpha$-Amylase } \\
\hline Conventional (Low) & $0.902 \pm 0.002^{\mathrm{a}}$ & $0.892 \pm 0.003^{\mathrm{a}}$ & $0.892 \pm 0.001^{\mathrm{a}}$ & $0.885 \pm 0.001^{\mathrm{a}}$ & $0.876 \pm 0.003^{\mathrm{a}}$ & $0.871 \pm 0.002^{\mathrm{a}}$ & + \\
\hline Conventional (Medium) & $0.902 \pm 0.003^{\mathrm{a}}$ & $0.893 \pm 0.003^{b}$ & $0.883 \pm 0.003^{\mathrm{bc}}$ & $0.879 \pm 0.003^{\mathrm{bc}}$ & $0.862 \pm 0.003^{\mathrm{c}}$ & $0.860 \pm 0.003^{b}$ & + \\
\hline Conventional (High) & $0.903 \pm 0.006^{\mathrm{a}}$ & $0.898 \pm 0.001^{\mathrm{a}}$ & $0.892 \pm 0.003^{\mathrm{a}}$ & $0.886 \pm 0.001^{\mathrm{a}}$ & $0.876 \pm 0.002^{\mathrm{a}}$ & $0.871 \pm 0.003^{\mathrm{a}}$ & + \\
\hline Fungi (Low) & $0.892 \pm 0.003^{\mathrm{b}}$ & $0.887 \pm 0.003^{\mathrm{f}}$ & $0.884 \pm 0.002^{\mathrm{d}}$ & $0.876 \pm 0.003^{\mathrm{a}}$ & $0.868 \pm 0.002^{\mathrm{b}}$ & $0.863 \pm 0.002^{b}$ & + \\
\hline Fungi (Medium) & $0.902 \pm 0.003^{\mathrm{a}}$ & $0.893 \pm 0.003^{b}$ & $0.883 \pm 0.003^{\mathrm{c}}$ & $0.881 \pm 0.003^{\mathrm{ab}}$ & $0.865 \pm 0.003^{\mathrm{bc}}$ & $0.864 \pm 0.003^{\mathrm{b}}$ & + \\
\hline Fungi (High) & $0.906 \pm 0.001^{\mathrm{a}}$ & $0.896 \pm 0.001^{\mathrm{ab}}$ & $0.888 \pm 0.001^{\mathrm{b}}$ & $0.882 \pm 0.003^{\mathrm{ab}}$ & $0.866 \pm 0.001^{\mathrm{bc}}$ & $0.864 \pm 0.001^{\mathrm{b}}$ & + \\
\hline Maltogenic (Low) & $0.902 \pm 0.002^{\mathrm{a}}$ & $0.892 \pm 0.003^{\mathrm{b}}$ & $0.886 \pm 0.001^{\mathrm{c}}$ & $0.876 \pm 0.001^{\mathrm{c}}$ & $0.864 \pm 0.003^{\mathrm{bc}}$ & $0.864 \pm 0.002^{\mathrm{b}}$ & + \\
\hline Maltogenic (Medium) & $0.900 \pm 0.001^{\mathrm{a}}$ & $0.893 \pm 0.003^{\mathrm{b}}$ & $0.883 \pm 0.003^{\mathrm{bc}}$ & $0.879 \pm 0.002^{\mathrm{bc}}$ & $0.862 \pm 0.003^{\mathrm{c}}$ & $0.861 \pm 0.003^{\mathrm{a}}$ & + \\
\hline Maltogenic (High) & $0.903 \pm 0.006^{\mathrm{a}}$ & $0.898 \pm 0.001^{\mathrm{a}}$ & $0.892 \pm 0.003^{\mathrm{a}}$ & $0.886 \pm 0.001^{\mathrm{a}}$ & $0.876 \pm 0.002^{\mathrm{a}}$ & $0.871 \pm 0.003^{\mathrm{a}}$ & + \\
\hline \multicolumn{8}{|c|}{ Gums } \\
\hline Xanthan (Low) & $0.902 \pm 0.003^{\mathrm{ab}}$ & $0.891 \pm 0.001^{\mathrm{bc}}$ & $0.887 \pm 0.001^{\mathrm{b}}$ & $0.882 \pm 0.002^{\mathrm{b}}$ & $0.878 \pm 0.002^{\mathrm{bc}}$ & $0.870 \pm 0.003^{b}$ & + \\
\hline Xanthan (Medium) & $0.902 \pm 0.003^{\mathrm{ab}}$ & $0.896 \pm 0.001^{\mathrm{a}}$ & $0.892 \pm 0.003^{\mathrm{a}}$ & $0.887 \pm 0.002^{\mathrm{a}}$ & $0.884 \pm 0.003^{\mathrm{a}}$ & $0.880 \pm 0.002^{\mathrm{a}}$ & + \\
\hline Xanthan (High) & $0.902 \pm 0.004^{\mathrm{c}}$ & $0.887 \pm 0.004^{\mathrm{c}}$ & $0.885 \pm 0.002^{\mathrm{bc}}$ & $0.882 \pm 0.003^{b}$ & $0.876 \pm 0.002^{\mathrm{b}}$ & $0.868 \pm 0.003^{b}$ & + \\
\hline Guar Gum (Low) & $0.903 \pm 0.006^{\mathrm{a}}$ & $0.896 \pm 0.00^{\mathrm{a}}$ & $0.888 \pm 0.002^{\mathrm{b}}$ & $0.878 \pm 0.002^{\mathrm{c}}$ & $0.872 \pm 0.002^{\mathrm{c}}$ & + & + \\
\hline Guar Gum (Medium) & $0.896 \pm 0.001^{\mathrm{bc}}$ & $0.888 \pm 0.001^{\mathrm{c}}$ & $0.883 \pm 0.002^{\mathrm{c}}$ & $0.883 \pm 0.002^{b}$ & $0.878 \pm 0.002^{\mathrm{b}}$ & + & + \\
\hline Guar Gum (High) & $0.900 \pm 0.001^{\mathrm{ab}}$ & $0.892 \pm 0.003^{\mathrm{b}}$ & $0.887 \pm 0.002^{\mathrm{b}}$ & $0.885 \pm 0.001^{\mathrm{ab}}$ & $0.884 \pm 0.003^{\mathrm{a}}$ & + & + \\
\hline \multicolumn{8}{|c|}{ Emulsifier } \\
\hline Monoglyceride (Low) & $0.884 \pm 0.003^{\mathrm{a}}$ & $0.877 \pm 0.001^{\mathrm{b}}$ & $0.873 \pm 0.054^{\mathrm{b}}$ & $0.871 \pm 0.003^{\mathrm{a}}$ & $0.864 \pm 0.002^{\mathrm{b}}$ & $0.858 \pm 0.001^{\mathrm{c}}$ & $0.849 \pm 0.005^{\mathrm{c}}$ \\
\hline Monoglyceride (Medium) & $0.883 \pm 0.003^{\mathrm{a}}$ & $0.878 \pm 0.001^{\mathrm{b}}$ & $0.871 \pm 0.054^{\mathrm{c}}$ & $0.869 \pm 0.003^{\mathrm{b}}$ & $0.865 \pm 0.002^{\mathrm{b}}$ & $0.860 \pm 0.001^{\mathrm{b}}$ & $0.855 \pm 0.002^{\mathrm{b}}$ \\
\hline Monoglyceride (High) & $0.884 \pm 0.003^{\mathrm{a}}$ & $0.880 \pm 0.001^{\mathrm{a}}$ & $0.877 \pm 0.054^{\mathrm{a}}$ & $0.872 \pm 0.003^{\mathrm{a}}$ & $0.868 \pm 0.002^{\mathrm{a}}$ & $0.865 \pm 0.001^{\mathrm{a}}$ & $0.858 \pm 0.004^{\mathrm{a}}$ \\
\hline
\end{tabular}

$(+)$ Mold grew on the external surface of bread

Values in the same column followed by different letters differ significantly $(\mathrm{p}<0.05)$. 
Table 3: Effect of additives on moisture loss (\%) of flatbread after different storage period

\begin{tabular}{|c|c|c|c|c|c|c|}
\hline Treatment & $\%$ Loss after $24 h$ & $\%$ Loss after $48 \mathrm{~h}$ & $\%$ Loss after $72 h$ & $\%$ Loss after $96 \mathrm{~h}$ & $\begin{array}{c}\text { \% Loss after } \\
120 \mathrm{~h}\end{array}$ & $\begin{array}{c}\% \text { Loss after } \\
144 h\end{array}$ \\
\hline Control & $1.97 \pm 0.03$ & $3.12 \pm 0.32$ & $6.04 \pm 0.53$ & $9.65 \pm 0.02$ & + & + \\
\hline \multicolumn{7}{|c|}{$\alpha$-Amylase } \\
\hline Conventional (Low) & $1.61 \pm 0.18^{\mathrm{a}}$ & $2.88 \pm 0.31^{\mathrm{ab}}$ & $4.17 \pm 0.04^{\mathrm{a}}$ & $6.95 \pm 0.11^{\mathrm{a}}$ & $8.45 \pm 0.08^{\mathrm{a}}$ & + \\
\hline Conventional (Medium) & $1.38 \pm 0.09^{\mathrm{bcd}}$ & $2.13 \pm 0.10^{\text {def }}$ & $3.56 \pm 0.04^{b}$ & $6.24 \pm 0.08^{\mathrm{bc}}$ & $7.96 \pm 0.03^{\mathrm{ab}}$ & + \\
\hline Conventional (High) & $1.14 \pm 0.10^{\text {ef }}$ & $1.83 \pm 0.10^{\text {ef }}$ & $3.29 \pm 0.09^{\mathrm{bc}}$ & $5.74 \pm 0.06^{\mathrm{cd}}$ & $6.48 \pm 0.08^{\mathrm{de}}$ & + \\
\hline Fungi (Low) & $1.54 \pm 0.01^{\mathrm{ab}}$ & $2.61 \pm 0.18^{\mathrm{bc}}$ & $4.34 \pm 0.06^{\mathrm{a}}$ & $6.38 \pm 0.06^{\mathrm{b}}$ & $8.01 \pm 0.05^{\mathrm{ab}}$ & + \\
\hline Fungi (Medium) & $1.44 \pm 0.14^{\mathrm{abcd}}$ & $2.48 \pm 0.12^{\mathrm{bcd}}$ & $4.33 \pm 0.18^{\mathrm{a}}$ & $5.93 \pm 0.47^{\mathrm{bcd}}$ & $7.05 \pm 1.10^{\mathrm{cd}}$ & + \\
\hline Fungi (High) & $1.33 \pm 0.14^{\text {cde }}$ & $2.28 \pm 0.13^{\mathrm{cd}}$ & $3.44 \pm 0.10^{\mathrm{bc}}$ & $5.14 \pm 0.45^{\mathrm{e}}$ & $6.12 \pm 0.04^{\mathrm{e}}$ & + \\
\hline Maltogenic (Low) & $1.52 \pm 0.13^{\mathrm{abc}}$ & $2.16 \pm 0.01^{\mathrm{de}}$ & $3.65 \pm 0.09^{b}$ & $6.42 \pm 0.21^{\mathrm{b}}$ & $8.53 \pm 0.12^{\mathrm{a}}$ & + \\
\hline Maltogenic (Medium) & $1.31 \pm 0.10^{\mathrm{de}}$ & $2.07 \pm 0.14^{\mathrm{def}}$ & $3.46 \pm 0.04^{b c}$ & $6.18 \pm 0.66^{\mathrm{bc}}$ & $7.65 \pm 0.09^{b c}$ & + \\
\hline Maltogenic (High) & $1.00 \pm 0.05^{\mathrm{f}}$ & $1.70 \pm 0.52^{\mathrm{f}}$ & $3.11 \pm 0.14^{\mathrm{c}}$ & $5.42 \pm 0.08^{\mathrm{de}}$ & $6.90 \pm 0.09^{\mathrm{d}}$ & + \\
\hline \multicolumn{7}{|c|}{ Gums } \\
\hline Xanthan (Low) & $1.68 \pm 0.05^{\mathrm{a}}$ & $2.35 \pm 0.11^{\mathrm{a}}$ & $4.23 \pm 0.40^{\mathrm{ab}}$ & $6.47 \pm 0.01^{\mathrm{a}}$ & $9.73 \pm 0.02^{\mathrm{a}}$ & + \\
\hline Xanthan (Medium) & $1.48 \pm 0.05^{\mathrm{b}}$ & $2.10 \pm 0.02^{\mathrm{ab}}$ & $3.96 \pm 0.32^{\mathrm{abc}}$ & $5.60 \pm 0.02^{\mathrm{bc}}$ & $7.88 \pm 0.01^{\mathrm{bc}}$ & + \\
\hline Xanthan (High) & $1.34 \pm 0.01^{\mathrm{c}}$ & $1.88 \pm 0.02^{\mathrm{b}}$ & $3.50 \pm 0.02^{\mathrm{abc}}$ & $5.25 \pm 0.03^{\mathrm{c}}$ & $6.86 \pm 0.02^{\mathrm{c}}$ & + \\
\hline Guar Gum (Low) & $1.41 \pm 0.07^{\mathrm{bc}}$ & $2.18 \pm 0.12^{\mathrm{ab}}$ & $4.42 \pm 0.08^{\mathrm{a}}$ & $6.24 \pm 0.29^{\mathrm{ab}}$ & $8.66 \pm 0.01^{\mathrm{b}}$ & + \\
\hline Guar Gum (Medium) & $1.23 \pm 0.01^{\mathrm{d}}$ & $2.05 \pm 0.04^{\mathrm{ab}}$ & $3.35 \pm 0.04^{\mathrm{bc}}$ & $5.67 \pm 0.04^{\mathrm{bc}}$ & $7.07 \pm 0.08^{\mathrm{bc}}$ & + \\
\hline Guar Gum (High) & $1.01 \pm 0.14^{\mathrm{e}}$ & $1.82 \pm 0.36^{\mathrm{b}}$ & $3.15 \pm 1.06^{\mathrm{c}}$ & $4.53 \pm 1.00^{\mathrm{d}}$ & $6.00 \pm 0.98^{\mathrm{c}}$ & + \\
\hline \multicolumn{7}{|c|}{ Emulsifier } \\
\hline Monoglyceride (Low) & $1.37 \pm 0.22^{\mathrm{a}}$ & $2.16 \pm 0.19^{\mathrm{a}}$ & $3.91 \pm 0.20^{\mathrm{a}}$ & $6.40 \pm 0.22^{\mathrm{a}}$ & $6.80 \pm 0.21^{\mathrm{a}}$ & $8.49 \pm 0.19^{\mathrm{a}}$ \\
\hline Monoglyceride (Medium) & $1.18 \pm 0.21^{\mathrm{a}}$ & $1.92 \pm 0.23^{\mathrm{ab}}$ & $3.68 \pm 0.19^{\mathrm{a}}$ & $5.48 \pm 0.20^{\mathrm{b}}$ & $6.26 \pm 0.26^{\mathrm{b}}$ & $7.27 \pm 0.20^{\mathrm{b}}$ \\
\hline Monoglyceride (High) & $1.01 \pm 0.10^{\mathrm{a}}$ & $1.64 \pm 0.02^{\mathrm{b}}$ & $3.05 \pm 0.19^{\mathrm{b}}$ & $4.70 \pm 0.01^{\mathrm{c}}$ & $5.63 \pm 0.01^{\mathrm{c}}$ & $6.74 \pm 0.04^{c}$ \\
\hline
\end{tabular}

$(+)$ Mold grew on the external surface of bread

Values in the same column followed by different letters differ significantly $(\mathrm{p}<0.05)$. 


\subsection{Effect of additives on gumminess of flatbread after different storage period}

The results from Table (4) observed that the gumminess (a parameter that is mostly dependent on firmness). Bread gumminess significantly increased over storage time. These results agree with Crowley et al. (2002) \& Kotancilar et al. (2008) who explained that the increase of firmness may cause an increase in the values of gumminess and chewiness of bread during storage period.

Generally, the experiment proved that for all breads firmness and gumminess increased during the time of storage from 1 to 5 days. However, those changes were always stronger for the control than for breads with additives.

It could be noticed that all textural changes found to have a negative impact on the quality of flat bread, e.g. the bread become sharder (increased firmness), requires more energy to disintegrate during chewing (increased gumminess) and requires a longer time for mastication (increased chewiness). These findings agree with results of Crowley et al. (2002).

\subsection{Effect of additives on organoleptic evaluation of flat bread}

The preference for the products in terms of the sensory characters was used in evaluating the product. Sensory evaluation is unique since it uses human senses, experimental design and statistical analysis with the aim of evaluating consumer response to products. The mean scores of sensory attributes of the bread are given in Table (5). Our data show that there was a slight significant effect of different additives on the aroma and overall score. Meanwhile all other parameters showed no significant difference. These results agree with work by Guarda et al. (2004).

\subsection{Effect of combined additives on flat bread quality after different storage period}

Tables (6 to10) shows the effect of using 2 and 3 anti-stalling agents on flat bread. The effect of additives on flat bread was more obvious when emulsifiers were used in combination with different $\alpha$ amylase. It can be noticed a decrease in firmness when enzymes and emulsifier were combined compared with using one of them. These results agree with work of Koocheki et al. (2009). They reported that the effect of both emulsifiers and fungal $\alpha$-amylase on reducing bread firmness was more pronounced compared with when either was used separately.

There was a significant combined effect on the firmness of flat bread. The addition of (Xanthan $($ Medium $)+$ Maltogenic (Medium) + EM (Medium)) and (Xanthan (Medium)+ Fungi (Medium)+ EM (Medium)resulted in a decrease in firmness and gumminess of bread. During storage, firmness and gumminess increased for all breads, but these changes, were always lower for the of (Xanthan (Medium) + Maltogenic (Medium)+ EM (Medium)) or (Xanthan (Medium)+ Fungi (Medium)+ EM Med) combinations for breads, confirming the anti-staling activity of the mixtures used. Aleid et al., 2015 found that there was a significant interaction effect of (Arabic gum*Monoglycerides*alpha-amylase) on the crumb texture as well as on the crumb appearance of the Arabic bread

The free water present in the freshly baked flat bread which gave higher water activity values was probably bound to the hydrophilic constituents (e.g. starch) of the flat bread during storage. Results agree with work by Aleid et al. (2015).

From previous results it is found that the optimum formulation for flat bread contained a combination of hydrocolloid (Xanthan), $\alpha$-amylase (Maltogeneric) and emulsifiers. These results agree with work by Patil et al. (2019) they found that staling rate was successfully retarded with the help of combination of hydrocolloids and emulsifiers for gluten free flat bread.

There was significant combined effect of (Xanthan (Medium) + Fungi (Medium)+ EM (Medium)) and (Maltogenic (Medium)+ Fungi (Medium)+ EM (Medium)) on overall score when compared with other treatments. The results are similar to those found by Aleid et al. (2015). They found that there was significant interaction effect due to (Arabic gum* Monoglycerides* alpha-amylase) combination on total score of Arabic white bread. It can be concluded that these two formulas can be used to improve the quality and of Arabic white bread. 
Table 4: Effect of additives on gumminess $(\mathrm{N})$ of flatbread after different storage period

\begin{tabular}{|c|c|c|c|c|c|c|c|}
\hline Treatment & O hour & 24 hours & 48 hours & 72 hours & 96 hours & 120 hours & 144 hours \\
\hline Control & $32.00 \pm 0.05$ & $37.47 \pm 0.09$ & $41.55 \pm 0.07$ & $46.85 \pm 0.11$ & $50.14 \pm 0.03$ & + & + \\
\hline \multicolumn{8}{|c|}{$\alpha$-Amylase } \\
\hline Conventional (Low) & $25.54 \pm 0.08^{\mathrm{a}}$ & $26.57 \pm 0.03^{\mathrm{a}}$ & $27.23 \pm 0.06^{\mathrm{a}}$ & $28.78 \pm 0.04^{\mathrm{a}}$ & $30.68 \pm 0.08^{\mathrm{a}}$ & $31.36 \pm 0.05^{\mathrm{a}}$ & + \\
\hline Conventional (Medium) & $23.14 \pm 0.02^{\mathrm{c}}$ & $24.23 \pm 0.07^{b}$ & $26.55 \pm 0.04^{\mathrm{b}}$ & $27.08 \pm 0.06^{\mathrm{b}}$ & $28.13 \pm 0.05^{\mathrm{b}}$ & $29.23 \pm 0.12^{b}$ & + \\
\hline Conventional (High) & $22.73 \pm 0.03^{\mathrm{d}}$ & $23.11 \pm 0.07^{\mathrm{c}}$ & $23.16 \pm 0.06^{\mathrm{c}}$ & $23.78 \pm 0.07^{\mathrm{d}}$ & $24.16 \pm 0.12^{\mathrm{d}}$ & $24.70 \pm 0.10^{\mathrm{d}}$ & + \\
\hline Fungi (Low) & $22.73 \pm 0.05^{\mathrm{d}}$ & $23.11 \pm 0.07^{\mathrm{c}}$ & $23.14 \pm 0.02^{\mathrm{c}}$ & $23.78 \pm 0.04^{\mathrm{d}}$ & $24.16 \pm 0.05^{\mathrm{d}}$ & $24.73 \pm 0.12^{\mathrm{d}}$ & + \\
\hline Fungi (Medium) & $20.21 \pm 0.02^{\mathrm{e}}$ & $23.86 \pm 0.07^{\mathrm{d}}$ & $23.13 \pm 0.09^{c}$ & $24.28 \pm 0.06^{\mathrm{c}}$ & $25.98 \pm 0.05^{\mathrm{c}}$ & $26.72 \pm 0.17^{\mathrm{b}}$ & + \\
\hline Fungi (High) & $23.14 \pm 0.07^{\mathrm{c}}$ & $24.23 \pm 0.04^{b}$ & $26.52 \pm 0.06^{\mathrm{b}}$ & $27.08 \pm 0.03^{b}$ & $28.10 \pm 0.15^{\mathrm{b}}$ & $29.23 \pm 0.15^{\mathrm{b}}$ & + \\
\hline Maltogenic (Low) & $25.54 \pm 0.04^{\mathrm{a}}$ & $26.57 \pm 0.06^{\mathrm{a}}$ & $27.25 \pm 0.03^{\mathrm{a}}$ & $28.75 \pm 0.03^{\mathrm{a}}$ & $30.58 \pm 0.11^{\mathrm{a}}$ & $31.26 \pm 0.07^{\mathrm{a}}$ & + \\
\hline Maltogenic (Medium) & $25.16 \pm 0.02^{\mathrm{b}}$ & $26.57 \pm 0.03^{\mathrm{a}}$ & $27.23 \pm 0.07^{\mathrm{a}}$ & $28.77 \pm 0.06^{\mathrm{a}}$ & $30.60 \pm 0.08^{a}$ & $31.30 \pm 0.09^{\mathrm{a}}$ & + \\
\hline Maltogenic (High) & $25.54 \pm 0.07^{\mathrm{a}}$ & $26.57 \pm 0.05^{\mathrm{a}}$ & $27.20 \pm 0.02^{\mathrm{a}}$ & $28.75 \pm 0.04^{\mathrm{a}}$ & $30.68 \pm 0.18^{a}$ & $31.36 \pm 0.05^{\mathrm{a}}$ & + \\
\hline \multicolumn{8}{|c|}{ Gums } \\
\hline Xanthan (Low) & $25.23 \pm 0.02^{\mathrm{a}}$ & $29.51 \pm 0.03^{b}$ & $33.13 \pm 0.56^{\mathrm{b}}$ & $38.18 \pm 0.03^{\mathrm{d}}$ & $42.72 \pm 1.18^{\mathrm{b}}$ & $45.93 \pm 0.03^{\mathrm{a}}$ & + \\
\hline Xanthan (Medium) & $24.52 \pm 0.02^{\mathrm{b}}$ & $27.13 \pm 0.03^{\mathrm{a}}$ & $32.72 \pm 0.03^{\mathrm{a}}$ & $37.47 \pm 0.03^{\mathrm{d}}$ & $40.93 \pm 0.06^{\mathrm{a}}$ & $43.73 \pm 0.03^{\mathrm{b}}$ & + \\
\hline Xanthan (High) & $23.91 \pm 0.02^{\mathrm{c}}$ & $25.61 \pm 0.03^{\mathrm{d}}$ & $30.46 \pm 0.03^{c}$ & $35.46 \pm 0.03^{\mathrm{c}}$ & $39.83 \pm 0.03^{c}$ & $41.86 \pm 0.03^{\mathrm{c}}$ & + \\
\hline Guar Gum (Low) & $22.15 \pm 0.13^{\mathrm{d}}$ & $24.40 \pm 0.04^{\mathrm{e}}$ & $27.47 \pm 0.55^{\mathrm{d}}$ & $38.18 \pm 0.03^{\mathrm{d}}$ & $42.52 \pm 0.03^{\mathrm{d}}$ & + & + \\
\hline Guar Gum (Medium) & $21.92 \pm 0.03^{b}$ & $24.53 \pm 0.08^{\mathrm{d}}$ & $28.40 \pm 0.05^{\mathrm{c}}$ & $37.40 \pm 0.03^{\mathrm{c}}$ & $41.82 \pm 0.03^{c}$ & + & + \\
\hline Guar Gum (High) & $21.11 \pm 0.15^{\mathrm{e}}$ & $24.35 \pm 0.02^{\mathrm{e}}$ & $27.18 \pm 0.02^{\mathrm{d}}$ & $37.18 \pm 0.03^{\mathrm{d}}$ & $41.23 \pm 0.03^{\mathrm{e}}$ & + & + \\
\hline \multicolumn{8}{|c|}{ Emulsifier } \\
\hline Monoglyceride (Low) & $25.98 \pm 0.15^{\mathrm{a}}$ & $29.89 \pm 0.11^{\mathrm{a}}$ & $30.61 \pm 0.14^{\mathrm{a}}$ & $32.10 \pm 0.17^{\mathrm{a}}$ & $34.05 \pm 0.10^{\mathrm{a}}$ & $36.03 \pm 0.15^{\mathrm{a}}$ & $39.91 \pm 0.19^{\mathrm{a}}$ \\
\hline Monoglyceride (Medium) & $26.01 \pm 0.10^{\mathrm{a}}$ & $29.91 \pm 0.17^{\mathrm{a}}$ & $30.63 \pm 0.15^{\mathrm{a}}$ & $32.13 \pm 0.13^{\mathrm{a}}$ & $34.03 \pm 0.12^{\mathrm{a}}$ & $36.05 \pm 0.09^{a}$ & $39.93 \pm 0.15^{\mathrm{a}}$ \\
\hline Monoglyceride (High) & $26.04 \pm 0.12^{\mathrm{a}}$ & $29.95 \pm 0.15^{\mathrm{a}}$ & $30.64 \pm 0.13^{\mathrm{a}}$ & $32.14 \pm 0.10^{\mathrm{a}}$ & $34.02 \pm 0.18^{\mathrm{a}}$ & $36.08 \pm 0.05^{\mathrm{a}}$ & $39.96 \pm 0.13^{a}$ \\
\hline
\end{tabular}

$(+)$ Mold grew on the external surface of bread

Values in the same column followed by different letters differ significantly $(\mathrm{p}<0.05)$. 
Table 5: Organoleptic evaluation of fresh bread containing selected gums, emulsifiers and enzyme

\begin{tabular}{|c|c|c|c|c|c|c|c|}
\hline Treatment & $\begin{array}{c}\text { Aroma } \\
(10)\end{array}$ & $\begin{array}{l}\text { Taste } \\
\text { (10) }\end{array}$ & $\begin{array}{c}\text { Texture } \\
(10)\end{array}$ & $\begin{array}{c}\text { Colour } \\
(10)\end{array}$ & $\begin{array}{c}\text { Separation } \\
(\mathbf{1 0})\end{array}$ & $\begin{array}{l}\text { Tear } \\
\text { (10) }\end{array}$ & $\begin{array}{c}\text { Overall } \\
(60)\end{array}$ \\
\hline Control & $9.04 \pm 1.15$ & $9.04 \pm 1.00$ & $8.73 \pm 1.22$ & $9.12 \pm 1.28$ & $9.34 \pm 1.21$ & $8.52 \pm 1.43$ & $53.78 \pm 5.55$ \\
\hline \multicolumn{8}{|c|}{$\alpha$-Amylase } \\
\hline Conventional (Medium) & $8.67 \pm 1.15^{\mathrm{ab}}$ & $9.00 \pm 1.00^{\mathrm{a}}$ & $8.67 \pm 1.15^{\mathrm{a}}$ & $9.00 \pm 1.00^{\mathrm{a}}$ & $8.35 \pm 1.53^{\mathrm{a}}$ & $8.65 \pm 1.15^{\mathrm{a}}$ & $52.33 \pm 6.81^{\mathrm{ab}}$ \\
\hline Conventional (Low) & $8.65 \pm 1.15^{\mathrm{ab}}$ & $9.00 \pm 1.00^{\mathrm{a}}$ & $8.67 \pm 1.15^{\mathrm{a}}$ & $8.67 \pm 1.05^{\mathrm{a}}$ & $8.30 \pm 1.50^{\mathrm{a}}$ & $8.63 \pm 1.13^{\mathrm{a}}$ & $52.00 \pm 7.00^{\mathrm{ab}}$ \\
\hline Conventional (High) & $8.6 \pm 1.15^{\mathrm{ab}}$ & $9.00 \pm 1.00^{\mathrm{a}}$ & $8.67 \pm 1.15^{\mathrm{a}}$ & $9.67 \pm 0.58^{\mathrm{a}}$ & $8.67 \pm 1.15^{\mathrm{a}}$ & $8.67 \pm 1.17^{\mathrm{a}}$ & $53.33 \pm 5.77^{\mathrm{ab}}$ \\
\hline Fungi (Low) & $8.85 \pm 1.28^{\mathrm{ab}}$ & $9.15 \pm 1.21^{\mathrm{a}}$ & $9.00 \pm 1.00^{\mathrm{a}}$ & $8.50 \pm 0.81^{\mathrm{a}}$ & $9.28 \pm 1.47^{\mathrm{a}}$ & $9.15 \pm 0.99^{\mathrm{a}}$ & $54.45 \pm 3.31^{\mathrm{ab}}$ \\
\hline Fungi (Medium) & $9.00 \pm 0.99^{\mathrm{ab}}$ & $8.62 \pm 1.26^{\mathrm{a}}$ & $9.10 \pm 1.00^{\mathrm{a}}$ & $8.92 \pm 1.19^{\mathrm{a}}$ & $9.30 \pm 1.46^{\mathrm{a}}$ & $8.92 \pm 1.26^{\mathrm{a}}$ & $53.92 \pm 4.11^{\mathrm{ab}}$ \\
\hline Fungi (High) & $9.15 \pm 0.90^{\mathrm{ab}}$ & $8.92 \pm 0.86^{\mathrm{a}}$ & $8.85 \pm 1.28^{\mathrm{a}}$ & $9.08 \pm 0.86^{\mathrm{a}}$ & $9.38 \pm 1.47^{\mathrm{a}}$ & $8.77 \pm 1.24^{\mathrm{a}}$ & $54.15 \pm 3.24^{\mathrm{ab}}$ \\
\hline Maltogenic (Low) & $9.46 \pm 0.88^{\mathrm{ab}}$ & $9.00 \pm 1.00^{\mathrm{a}}$ & $8.85 \pm 1.28^{\mathrm{a}}$ & $8.85 \pm 1.14^{\mathrm{a}}$ & $9.07 \pm 1.52^{\mathrm{a}}$ & $9.31 \pm 0.85^{\mathrm{a}}$ & $54.53 \pm 2.93^{\mathrm{ab}}$ \\
\hline Maltogenic (Medium) & $9.15 \pm 0.99^{\mathrm{ab}}$ & $8.92 \pm 1.04^{\mathrm{a}}$ & $9.15 \pm 0.91^{\mathrm{a}}$ & $9.15 \pm 0.80^{\mathrm{a}}$ & $9.22 \pm 1.50^{\mathrm{a}}$ & $9.38 \pm 0.77^{\mathrm{a}}$ & $54.99 \pm 3.34^{\mathrm{ab}}$ \\
\hline Maltogenic (High) & $9.00 \pm 1.00^{\mathrm{ab}}$ & $9.23 \pm 1.01^{\mathrm{a}}$ & $9.15 \pm 0.95^{\mathrm{a}}$ & $8.85 \pm 1.14^{\mathrm{a}}$ & $8.92 \pm 1.73^{\mathrm{a}}$ & $9.31 \pm 0.95^{\mathrm{a}}$ & $54.45 \pm 3.67^{\mathrm{ab}}$ \\
\hline \multicolumn{8}{|c|}{ Gums } \\
\hline Xanthan (Low) & $8.67 \pm 0.58^{\mathrm{ab}}$ & $9.33 \pm 0.55^{\mathrm{a}}$ & $8.33 \pm 0.57^{\mathrm{a}}$ & $8.67 \pm 1.15^{\mathrm{a}}$ & $8.67 \pm 1.10^{\mathrm{a}}$ & $8.00 \pm 0.05^{\mathrm{a}}$ & $51.67 \pm 2.08^{b}$ \\
\hline Xanthan (Medium) & $8.50 \pm 0.84^{\mathrm{ab}}$ & $8.67 \pm 1.03^{\mathrm{a}}$ & $8.50 \pm 0.84^{\mathrm{a}}$ & $8.83 \pm 0.98^{\mathrm{a}}$ & $9.17 \pm 0.75^{\mathrm{a}}$ & $8.83 \pm 0.98^{\mathrm{a}}$ & $52.50 \pm 3.78^{\mathrm{ab}}$ \\
\hline Xanthan (High) & $8.33 \pm 0.58^{\mathrm{ab}}$ & $8.67 \pm 1.15^{\mathrm{a}}$ & $8.33 \pm 0.58^{\mathrm{a}}$ & $9.67 \pm 0.58^{\mathrm{a}}$ & $9.33 \pm 0.58^{\mathrm{a}}$ & $8.67 \pm 1.15^{\mathrm{a}}$ & $53.00 \pm 2.65^{\mathrm{ab}}$ \\
\hline Guar Gum (Low) & $8.67 \pm 0.58^{\mathrm{ab}}$ & $9.33 \pm 0.50^{\mathrm{a}}$ & $8.33 \pm 0.58^{\mathrm{a}}$ & $8.67 \pm 1.15^{\mathrm{a}}$ & $8.67 \pm 1.10^{\mathrm{a}}$ & $8.00 \pm 0.07^{\mathrm{a}}$ & $51.67 \pm 2.08^{b}$ \\
\hline Guar Gum (Medium) & $8.00 \pm 0.09^{b}$ & $8.67 \pm 1.12^{\mathrm{a}}$ & $8.00 \pm 0.05^{\mathrm{a}}$ & $8.67 \pm 1.15^{\mathrm{a}}$ & $9.00 \pm 1.00^{\mathrm{a}}$ & $9.00 \pm 1.05^{\mathrm{a}}$ & $51.33 \pm 4.16^{\mathrm{b}}$ \\
\hline Guar Gum (High) & $8.33 \pm 0.50^{\mathrm{ab}}$ & $8.67 \pm 1.15^{\mathrm{a}}$ & $8.33 \pm 0.58^{\mathrm{a}}$ & $9.67 \pm 0.50^{\mathrm{a}}$ & $9.33 \pm 0.56^{\mathrm{a}}$ & $8.67 \pm 1.15^{\mathrm{a}}$ & $53.00 \pm 2.65^{\mathrm{ab}}$ \\
\hline \multicolumn{8}{|c|}{ Emulsifier } \\
\hline Monoglyceride (Low) & $9.00 \pm 0.71^{\mathrm{ab}}$ & $9.15 \pm 0.75^{\mathrm{a}}$ & $9.40 \pm 0.81^{\mathrm{a}}$ & $9.13 \pm 0.98^{\mathrm{a}}$ & $9.55 \pm 0.83^{\mathrm{a}}$ & $9.15 \pm 0.75^{\mathrm{a}}$ & $55.3 \pm 3.63^{\mathrm{ab}}$ \\
\hline Monoglyceride (Medium) & $9.45 \pm 0.69^{\mathrm{ab}}$ & $9.25 \pm 0.79^{\mathrm{a}}$ & $9.15 \pm 0.88^{\mathrm{ab}}$ & $8.98 \pm 0.92^{\mathrm{a}}$ & $9.50 \pm 0.85^{\mathrm{a}}$ & $9.30 \pm 0.82^{\mathrm{a}}$ & $55.63 \pm 4.09^{\mathrm{ab}}$ \\
\hline Monoglyceride (High) & $9.67 \pm 0.58^{\mathrm{a}}$ & $9.67 \pm 0.50^{\mathrm{a}}$ & $9.50 \pm 0.51^{\mathrm{a}}$ & $9.60 \pm 0.53^{\mathrm{a}}$ & $9.67 \pm 0.55^{\mathrm{a}}$ & $9.67 \pm 0.59^{\mathrm{a}}$ & $57.77 \pm 3.28^{\mathrm{a}}$ \\
\hline
\end{tabular}

$(+)$ Mold grew on the external surface of bread

Values in the same column followed by different letters differ significantly $(\mathrm{p}<0.05)$. 
Table 6: Effect of combined of additives on firmness $(\mathrm{N})$ of flatbread after different storage period

\begin{tabular}{|c|c|c|c|c|c|c|c|}
\hline Treatment & O hour & 24 hours & 48 hours & 72 hours & 96 hours & 120 hours & 144 hours \\
\hline Control & $22.19 \pm 0.06$ & $31.10 \pm 0.06$ & $46.46 \pm 0.06$ & $69.48 \pm 0.02$ & $82.67 \pm 0.02$ & + & + \\
\hline \multicolumn{8}{|c|}{ Enzymes with Emulsifier } \\
\hline $\begin{array}{l}\text { Conventional (Medium)+ } \\
\text { Monoglyceride (Medium) }\end{array}$ & $21.82 \pm 0.05^{\mathrm{a}}$ & $25.31 \pm 0.09^{\mathrm{a}}$ & $30.58 \pm 0.03^{\mathrm{a}}$ & $33.63 \pm 0.07^{\mathrm{a}}$ & $35.60 \pm 0.05^{\mathrm{a}}$ & $40.11 \pm 0.05^{\mathrm{a}}$ & + \\
\hline $\begin{array}{l}\text { Fungi (Medium) + Monoglyceride } \\
\text { (Medium) }\end{array}$ & $21.61 \pm 0.02^{\mathrm{a}}$ & $25.00 \pm 0.05^{\mathrm{b}}$ & $29.77 \pm 0.08^{b}$ & $31.70 \pm 0.04^{\mathrm{b}}$ & $34.31 \pm 0.05^{\mathrm{b}}$ & $38.00 \pm 0.05^{\mathrm{b}}$ & + \\
\hline $\begin{array}{l}\text { Maltogenic (Medium)+ Monoglyceride } \\
\text { (Medium) }\end{array}$ & $21.68 \pm 0.03^{\mathrm{a}}$ & $24.49 \pm 0.06^{\mathrm{c}}$ & $29.40 \pm 0.05^{\mathrm{c}}$ & $32.00 \pm 0.05^{\mathrm{c}}$ & $34.46 \pm 0.05^{\mathrm{c}}$ & $38.11 \pm 0.05^{b}$ & + \\
\hline \multicolumn{8}{|c|}{ Enzymes, Emulsifier with Gums } \\
\hline $\begin{array}{l}\text { Xanthan (Medium)+ Conventional } \\
\text { (Medium)+ Monoglyceride (Medium) }\end{array}$ & $21.48 \pm 0.02^{\mathrm{a}}$ & $23.95 \pm 0.05^{\mathrm{a}}$ & $30.23 \pm 0.06^{\mathrm{a}}$ & $31.65 \pm 1.55^{\mathrm{b}}$ & $33.77 \pm 0.28^{\mathrm{a}}$ & $35.33 \pm 0.58^{\mathrm{a}}$ & $37.41 \pm 0.51^{\mathrm{a}}$ \\
\hline $\begin{array}{l}\text { Xanthan (Medium)+Maltogenic } \\
\text { (Medium)+ Monoglyceride (Medium) }\end{array}$ & $21.42 \pm 0.03^{\mathrm{b}}$ & $22.52 \pm 0.09^{c}$ & $28.77 \pm 0.06^{\mathrm{c}}$ & $29.28 \pm 0.08^{b}$ & $30.72 \pm 0.03^{\mathrm{c}}$ & $33.47 \pm 0.02^{\mathrm{c}}$ & $35.04 \pm 0.07^{c}$ \\
\hline $\begin{array}{l}\text { Xanthan (Medium)+ Fungi (Medium)+ } \\
\text { Monoglyceride (Medium) }\end{array}$ & $21.45 \pm 0.05^{\mathrm{b}}$ & $22.54 \pm 0.01^{\mathrm{c}}$ & $28.79 \pm 0.08^{c}$ & $29.27 \pm 0.06^{\mathrm{b}}$ & $30.87 \pm 0.02^{\mathrm{c}}$ & $33.41 \pm 0.07^{\mathrm{c}}$ & $35.07 \pm 0.06^{\mathrm{c}}$ \\
\hline $\begin{array}{l}\text { Guar Gum (Medium)+ Conventional } \\
\text { (Medium)+ Monoglyceride (Medium) }\end{array}$ & $21.44 \pm 0.02^{\mathrm{a}}$ & $23.65 \pm 0.05^{\mathrm{a}}$ & $30.33 \pm 0.06^{\mathrm{a}}$ & $31.69 \pm 1.55^{\mathrm{a}}$ & $33.77 \pm 0.28^{\mathrm{a}}$ & $35.33 \pm 0.58^{\mathrm{a}}$ & $37.48 \pm 0.51^{\mathrm{a}}$ \\
\hline $\begin{array}{l}\text { Guar Gum (Medium)+ Fungi } \\
\text { (Medium)+ Monoglyceride (Medium) }\end{array}$ & $21.41 \pm 0.04^{\mathrm{a}}$ & $22.62 \pm 0.03^{b}$ & $29.77 \pm 0.09^{b}$ & $30.21 \pm 0.06^{\mathrm{ab}}$ & $31.72 \pm 0.05^{\mathrm{b}}$ & $34.41 \pm 0.03^{b}$ & $36.09 \pm 0.08^{b}$ \\
\hline $\begin{array}{l}\text { Guar Gum (Medium)+ Maltogenic } \\
\text { (Medium) + Monoglyceride (Medium) }\end{array}$ & $21.40 \pm 0.03^{\mathrm{a}}$ & $22.66 \pm 0.08^{b}$ & $29.43 \pm 0.55^{\mathrm{b}}$ & $30.27 \pm 0.09^{\mathrm{ab}}$ & $31.72 \pm 0.03^{b}$ & $34.41 \pm 0.06^{\mathrm{b}}$ & $36.04 \pm 0.09^{b}$ \\
\hline
\end{tabular}

$(+)$ Mold grew on the external surface of bread

Values in the same column followed by different letters differ significantly $(\mathrm{p}<0.05)$. 
Table 7: Effect of Combined additives on gumminess $(\mathrm{N})$ of flatbread after different storage period

\begin{tabular}{|c|c|c|c|c|c|c|c|}
\hline Treatment & 0 hour & 24 hours & 48 hours & 72 hours & 96 hours & 120 hours & 144 hours \\
\hline Control & $32.00 \pm 0.05$ & $37.47 \pm 0.09$ & $41.55 \pm 0.07$ & $46.85 \pm 0.11$ & $50.14 \pm 0.03$ & + & + \\
\hline \multicolumn{8}{|c|}{ Enzymes with Emulsifier } \\
\hline $\begin{array}{l}\text { Conventional (Medium)+ } \\
\text { Monoglyceride (Medium) }\end{array}$ & $26.82 \pm 0.07^{\mathrm{a}}$ & $27.95 \pm 0.03^{\mathrm{a}}$ & $29.11 \pm 0.06^{\mathrm{a}}$ & $30.07 \pm 0.04^{\mathrm{a}}$ & $31.15 \pm 0.08^{\mathrm{a}}$ & $32.33 \pm 0.03^{\mathrm{a}}$ & + \\
\hline $\begin{array}{l}\text { Fungi (Medium)+ Monoglyceride } \\
\text { Med }\end{array}$ & $25.11 \pm 0.06^{\mathrm{b}}$ & $26.45 \pm 0.11^{\mathrm{b}}$ & $27.64 \pm 0.11^{\mathrm{b}}$ & $28.70 \pm 0.15^{\mathrm{b}}$ & $30.34 \pm 0.01^{b}$ & $31.11 \pm 0.07^{\mathrm{b}}$ & + \\
\hline $\begin{array}{l}\text { Maltogenic (Medium)+ } \\
\text { Monoglyceride (Medium) }\end{array}$ & $25.19 \pm 0.04^{\mathrm{b}}$ & $26.82 \pm 0.09^{b}$ & $27.90 \pm 0.14^{\mathrm{b}}$ & $28.95 \pm 0.07^{\mathrm{b}}$ & $30.50 \pm 0.05^{b}$ & $31.25 \pm 0.09^{\mathrm{b}}$ & + \\
\hline \multicolumn{8}{|c|}{ Enzymes, Emulsifier with Gums } \\
\hline $\begin{array}{l}\text { Xanthan (Medium)+ Conventional } \\
\text { (Medium)+ Monoglyceride (Medium) }\end{array}$ & $25.64 \pm 0.03^{\mathrm{a}}$ & $26.57 \pm 0.05^{\mathrm{a}}$ & $27.23 \pm 0.06^{\mathrm{a}}$ & $28.78 \pm 0.09^{\mathrm{a}}$ & $30.68 \pm 0.07^{\mathrm{a}}$ & $31.36 \pm 0.04^{\mathrm{a}}$ & $33.60 \pm 0.06^{\mathrm{a}}$ \\
\hline $\begin{array}{l}\text { Xanthan (Medium)+ Fungi } \\
\text { (Medium)+ Monoglyceride (Medium) }\end{array}$ & $23.18 \pm 0.02^{\mathrm{c}}$ & $24.27 \pm 0.09^{c}$ & $26.27 \pm 0.05^{\mathrm{c}}$ & $27.08 \pm 0.02^{\mathrm{c}}$ & $28.19 \pm 0.04^{\mathrm{c}}$ & $29.23 \pm 0.05^{\mathrm{c}}$ & $30.35 \pm 0.08^{c}$ \\
\hline $\begin{array}{l}\text { Xanthan (Medium)+Maltogenic } \\
\text { (Medium)+ Monoglyceride (Medium) }\end{array}$ & $23.14 \pm 0.07^{\mathrm{c}}$ & $24.23 \pm 0.03^{\mathrm{c}}$ & $26.22 \pm 0.08^{c}$ & $27.05 \pm 0.02^{\mathrm{c}}$ & $28.13 \pm 0.06^{\mathrm{c}}$ & $29.25 \pm 0.03^{c}$ & $30.33 \pm 0.09^{\mathrm{c}}$ \\
\hline $\begin{array}{l}\text { Guar Gum (Medium)+ Conventional } \\
\text { (Medium)+ Monoglyceride (Medium) }\end{array}$ & $25.66 \pm 0.05^{\mathrm{a}}$ & $26.57 \pm 0.02^{\mathrm{a}}$ & $27.23 \pm 0.03^{\mathrm{a}}$ & $28.78 \pm 0.09^{\mathrm{a}}$ & $30.68 \pm 0.11^{\mathrm{a}}$ & $31.46 \pm 0.06^{\mathrm{a}}$ & $33.66 \pm 0.06^{\mathrm{a}}$ \\
\hline $\begin{array}{l}\text { Guar Gum (Medium) + Fungi } \\
\text { (Medium) + Monoglyceride (Medium) }\end{array}$ & $23.64 \pm 0.03^{b}$ & $24.53 \pm 0.07^{b}$ & $26.52 \pm 0.05^{b}$ & $27.28 \pm 0.07^{b}$ & $29.13 \pm 0.02^{b}$ & $30.23 \pm 0.08^{b}$ & $31.39 \pm 0.04^{\mathrm{b}}$ \\
\hline $\begin{array}{l}\text { Guar Gum (Medium) + Maltogenic } \\
\text { (Medium)+ Monoglyceride (Medium) }\end{array}$ & $23.64 \pm 0.04^{b}$ & $24.53 \pm 0.11^{b}$ & $26.56 \pm 0.02^{b}$ & $27.25 \pm 0.15^{b}$ & $29.13 \pm 0.08^{b}$ & $30.23 \pm 0.09^{b}$ & $31.36 \pm 0.04^{\mathrm{b}}$ \\
\hline
\end{tabular}

$(+)$ Mold grew on the external surface of bread

Values in the same column followed by different letters differ significantly $(\mathrm{p}<0.05)$. 
Middle East J. Appl. Sci., 11(1): 277-292, 2021

EISSN: $2706-7947$ ISSN: 2077-4613

DOI: $10.36632 /$ mejas/2021.11.1.21

Table 8: Effect of combined additives on water activity of flatbread after different storage period

\begin{tabular}{|c|c|c|c|c|c|c|c|}
\hline Treatment & 0 hour & 24 hours & 48 hours & 72 hours & 96 hours & 120 hours & 144 hours \\
\hline Control & $\begin{array}{c}0.892 \\
\pm 0.002 \\
\end{array}$ & $\begin{array}{c}0.883 \\
\pm 0.003 \\
\end{array}$ & $\begin{array}{c}0.883 \\
\pm 0.002 \\
\end{array}$ & $\begin{array}{c}0.882 \\
\pm 0.003\end{array}$ & $\begin{array}{c}0.877 \\
\pm 0.002 \\
\end{array}$ & + & + \\
\hline \multicolumn{8}{|c|}{ Enzymes with Emulsifier } \\
\hline Conventional (Medium)+ Monoglyceride (Medium) & $0.902 \pm 0.005^{\mathrm{a}}$ & $0.896 \pm 0.003^{\mathrm{a}}$ & $0.888 \pm 0.009^{\mathrm{a}}$ & $0.888 \pm 0.004^{\mathrm{a}}$ & $0.880 \pm 0.006^{\mathrm{a}}$ & $0.874 \pm 0.004^{\mathrm{a}}$ & + \\
\hline Fungi (Medium)+ Monoglyceride (Medium) & $0.902 \pm 0.009^{\mathrm{a}}$ & $0.894 \pm 0.004^{\mathrm{b}}$ & $0.888 \pm 0.007^{\mathrm{a}}$ & $0.885 \pm 0.002^{\mathrm{b}}$ & $0.878 \pm 0.009^{\mathrm{b}}$ & $0.871 \pm 0.004^{\mathrm{b}}$ & + \\
\hline Maltogenic (Medium)+ Monoglyceride (Medium) & $0.903 \pm 0.006^{\mathrm{a}}$ & $0.895 \pm 0.002^{\mathrm{ab}}$ & $0.887 \pm 0.004^{\mathrm{a}}$ & $0.886 \pm 0.007^{\mathrm{b}}$ & $0.878 \pm 0.005^{\mathrm{b}}$ & $0.871 \pm 0.004^{\mathrm{b}}$ & + \\
\hline \multicolumn{8}{|c|}{ Enzymes, Emulsifier with Gums } \\
\hline $\begin{array}{l}\text { Xanthan (Medium)+ Conventional (Medium)+ Monoglyceride } \\
\text { (Medium) }\end{array}$ & $0.902 \pm 0.005^{\mathrm{a}}$ & $0.897 \pm 0.001^{\mathrm{a}}$ & $0.886 \pm 0.003^{\mathrm{a}}$ & $0.880 \pm 0.001^{\mathrm{ab}}$ & $0.877 \pm 0.007^{\mathrm{a}}$ & $0.869 \pm 0.003^{\mathrm{a}}$ & $0.861 \pm 0.002^{\mathrm{a}}$ \\
\hline Xanthan (Medium)+ Fungi (Medium)+ Monoglyceride (Medium) & $0.902 \pm 0.003^{\mathrm{a}}$ & $0.893 \pm 0.002^{\mathrm{ab}}$ & $0.883 \pm 0.005^{\mathrm{a}}$ & $0.882 \pm 0.003$ & $0.874 \pm 0.005^{\mathrm{a}}$ & $0.869 \pm 0.007^{\mathrm{a}}$ & $0.863 \pm 0.003^{\mathrm{a}}$ \\
\hline Xanthan (Medium)+Maltogenic (Medium)+ Monoglyceride (Medium) & $0.902 \pm 0.002^{\mathrm{a}}$ & $0.892 \pm 0.003^{\mathrm{b}}$ & $0.886 \pm 0.001^{\mathrm{a}}$ & $0.880 \pm 0.004^{\mathrm{ab}}$ & $0.875 \pm 0.003^{\mathrm{a}}$ & $0.870 \pm 0.005^{\mathrm{a}}$ & $0.861 \pm 0.002^{\mathrm{a}}$ \\
\hline $\begin{array}{l}\text { Guar Gum (Medium)+Conventional (Medium)+ Monoglyceride } \\
\text { (Medium) }\end{array}$ & $0.900 \pm 0.001^{\mathrm{a}}$ & $0.897 \pm 0.002^{\mathrm{a}}$ & $0.883 \pm 0.003^{\mathrm{a}}$ & $0.876 \pm 0.002^{\mathrm{b}}$ & $0.879 \pm 0.001^{\mathrm{a}}$ & $0.868 \pm 0.003^{\mathrm{a}}$ & $0.863 \pm 0.003^{\mathrm{a}}$ \\
\hline Guar Gum (Medium) + Fungi (Medium) + Monoglyceride (Medium) & $0.902 \pm 0.003^{\mathrm{a}}$ & $0.892 \pm 0.006^{\mathrm{b}}$ & $0.886 \pm 0.004^{\mathrm{a}}$ & $0.880 \pm 0.001^{\mathrm{ab}}$ & $0.875 \pm 0.003^{\mathrm{a}}$ & $0.870 \pm 0.004^{\mathrm{a}}$ & $0.861 \pm 0.002^{\mathrm{a}}$ \\
\hline $\begin{array}{l}\text { Guar Gum (Medium)+ Maltogenic (Medium)+ Monoglyceride } \\
\text { (Medium) }\end{array}$ & $0.902 \pm 0.002^{\mathrm{a}}$ & $0.892 \pm 0.003^{\mathrm{b}}$ & $0.886 \pm 0.001^{\mathrm{a}}$ & $0.880 \pm 0.005^{\mathrm{ab}}$ & $0.876 \pm 0.003^{\mathrm{a}}$ & $0.868 \pm 0.002^{\mathrm{a}}$ & $0.861 \pm 0.002^{\mathrm{a}}$ \\
\hline
\end{tabular}

(Medium)

$0.902 \pm 0.002^{\mathrm{a}}$

Values in the same column followed by different letters differ significantly $(\mathrm{p}<0.05)$.

Table 9: Effect of combined additives on water loss (\%) of flatbread after different storage period

\begin{tabular}{|c|c|c|c|c|c|c|}
\hline Treatment & \% Loss after $24 \mathrm{~h}$ & $\%$ Loss after $48 \mathrm{~h}$ & \% Loss after $72 \mathrm{~h}$ & $\%$ Loss after $96 \mathrm{~h}$ & $\%$ Loss after 120h & $\%$ Loss after $144 \mathrm{~h}$ \\
\hline Control & $1.97 \pm 0.03$ & $4.98 \pm 0.57$ & $7.85 \pm 0.33$ & $11.22 \pm 0.02$ & & \\
\hline \multicolumn{7}{|c|}{ Enzymes with Emulsifier } \\
\hline Conventional (Medium)+ Monoglyceride (Medium) & $0.68 \pm 0.12^{\mathrm{ab}}$ & $1.91 \pm 0.13^{\mathrm{c}}$ & $3.95 \pm 0.40^{\mathrm{a}}$ & $6.15 \pm 0.23^{\mathrm{ab}}$ & $8.71 \pm 0.23^{\text {a }}$ & $9.18 \pm 0.26^{\mathrm{a}}$ \\
\hline Fungi (Medium)+ Monoglyceride (Medium) & $0.52 \pm 0.09^{\mathrm{bc}}$ & $1.66 \pm 0.08^{\mathrm{d}}$ & $3.46 \pm 0.18^{\mathrm{b}}$ & $5.57 \pm 0.15^{\mathrm{c}}$ & $7.01 \pm 0.27^{\mathrm{b}}$ & $8.39 \pm 0.22^{b}$ \\
\hline Maltogenic (Medium)+ Monoglyceride (Medium) & $0.46 \pm 0.04^{\mathrm{c}}$ & $1.62 \pm 0.09^{\mathrm{ab}}$ & $3.11 \pm 0.21^{\mathrm{c}}$ & $5.54 \pm 0.11^{\mathrm{c}}$ & $6.98 \pm 0.24^{b}$ & $8.15 \pm 0.27^{\mathrm{bc}}$ \\
\hline \multicolumn{7}{|c|}{ Enzymes, Emulsifier with Gums } \\
\hline $\begin{array}{l}\text { Xanthan (Medium) + Conventional } \\
\text { (Medium)+Monoglyceride (Medium) }\end{array}$ & $0.75 \pm 0.07^{\mathrm{a}}$ & $2.38 \pm 0.21^{\mathrm{ab}}$ & $3.90 \pm 0.15^{\mathrm{a}}$ & $6.31 \pm 0.20^{\mathrm{a}}$ & $8.50 \pm 0.01^{\mathrm{a}}$ & $8.96 \pm 0.10^{\mathrm{a}}$ \\
\hline $\begin{array}{l}\text { Xanthan (Medium)+ Fungi } \\
\text { (Medium)+Monoglyceride (Medium) }\end{array}$ & $0.59 \pm 0.09^{\mathrm{abc}}$ & $2.34 \pm 0.15^{\mathrm{ab}}$ & $3.80 \pm 0.14^{\mathrm{ab}}$ & $5.69 \pm 00.21^{\mathrm{c}}$ & $6.82 \pm 0.21^{b}$ & $8.17 \pm 0.01^{\mathrm{bc}}$ \\
\hline $\begin{array}{l}\text { Xanthan (Medium)+ Maltogenic } \\
\text { (Medium)+Monoglyceride (Medium) }\end{array}$ & $0.59 \pm 0.10^{\mathrm{abc}}$ & $2.27 \pm 0.13^{\mathrm{d}}$ & $3.77 \pm 0.15^{\mathrm{ab}}$ & $5.67 \pm 0.26^{\mathrm{c}}$ & $6.79 \pm 0.16^{\mathrm{b}}$ & $7.93 \pm 0.13^{\mathrm{c}}$ \\
\hline $\begin{array}{l}\text { Guar gum (Medium) + Conventional (Medium)+ } \\
\text { Monoglyceride (Medium) }\end{array}$ & $0.69 \pm 0.21^{\mathrm{ab}}$ & $2.43 \pm 0.03^{\mathrm{a}}$ & $4.04 \pm 0.10^{\mathrm{a}}$ & $6.28 \pm 0.17^{\text {a }}$ & $8.47 \pm 0.13^{\mathrm{a}}$ & $8.92 \pm 0.05^{\text {a }}$ \\
\hline $\begin{array}{l}\text { Guar gum (Medium) + Fungi (Medium) } \\
\text { + Monoglyceride (Medium) }\end{array}$ & $0.59 \pm 0.07^{\mathrm{abc}}$ & $2.20 \pm 0.13^{\mathrm{b}}$ & $3.97 \pm 0.10^{\text {a }}$ & $5.86 \pm 0.27^{\mathrm{bc}}$ & $6.99 \pm 0.16^{b}$ & $8.34 \pm 0.09^{b}$ \\
\hline $\begin{array}{l}\text { Guar gum(Medium) + Maltogenic } \\
\text { (Medium)+Monoglyceride (Medium) }\end{array}$ & $0.60 \pm 0.05^{\mathrm{abc}}$ & $2.33 \pm 0.08^{\mathrm{ab}}$ & $3.90 \pm 0.10^{\mathrm{a}}$ & $5.86 \pm 0.20^{\mathrm{bc}}$ & $6.87 \pm 0.27^{b}$ & $8.12 \pm 0.06^{\mathrm{bc}}$ \\
\hline
\end{tabular}

(Medium)+Monoglyceride (Medium)

$(+)$ Mold grew on the external surface of bread
Values in the same column followed by different letters differ significantly $(\mathrm{p}<0.05)$. 
Table 10: Organoleptic evaluation of fresh bread containing selected emulsifiers and enzyme

\begin{tabular}{|c|c|c|c|c|c|c|c|}
\hline $\begin{array}{l}\text { Treatment } \\
\text { Control }\end{array}$ & $\begin{array}{c}\text { Aroma } \\
\quad(\mathbf{1 0}) \\
9.04 \pm 1.15\end{array}$ & $\begin{array}{c}\text { Taste } \\
(\mathbf{1 0}) \\
9.04 \pm 1.00\end{array}$ & $\begin{array}{c}\text { Texture } \\
\mathbf{( 1 0 )} \\
8.73 \pm 1.22\end{array}$ & $\begin{array}{c}\text { Color } \\
(\mathbf{1 0}) \\
9.12 \pm 1.28\end{array}$ & $\begin{array}{c}\text { Separation } \\
(\mathbf{1 0}) \\
9.34 \pm 1.21 \\
\end{array}$ & $\begin{array}{c}\text { Tear } \\
(\mathbf{1 0}) \\
8.52 \pm 1.43 \\
\end{array}$ & $\begin{array}{c}\begin{array}{l}\text { Overall } \\
(\mathbf{6 0}) \\
53.78 \pm 5.55\end{array} \\
\end{array}$ \\
\hline \multicolumn{8}{|c|}{ Enzymes with Emulsifier } \\
\hline $\begin{array}{l}\text { Conventional (Medium)+ } \\
\text { Monoglyceride (Medium) }\end{array}$ & $8.00 \pm 0.09^{b}$ & $8.33 \pm 1.53^{b}$ & $8.00 \pm 0.20^{\mathrm{b}}$ & $9.00 \pm 1.00^{\mathrm{a}}$ & $8.67 \pm 1.15^{b}$ & $8.67 \pm 1.15^{\mathrm{a}}$ & $50.67 \pm 2.62^{b}$ \\
\hline $\begin{array}{l}\text { Fungi (Medium) + Monoglyceride } \\
\text { (Medium) }\end{array}$ & $8.67 \pm 1.15^{\mathrm{a}}$ & $9.00 \pm 1.00^{\mathrm{a}}$ & $8.66 \pm 1.15^{\mathrm{a}}$ & $8.33 \pm 0.58^{b}$ & $9.00 \pm 1.00^{\mathrm{a}}$ & $8.67 \pm 1.10^{\mathrm{a}}$ & $52.33 \pm 3.10^{\mathrm{a}}$ \\
\hline $\begin{array}{l}\text { Maltogenic (Medium)+ } \\
\text { Monoglyceride (Medium) }\end{array}$ & $8.69 \pm 1.10^{\mathrm{a}}$ & $9.00 \pm 1.05^{\mathrm{a}}$ & $8.68 \pm 1.12^{\mathrm{a}}$ & $8.35 \pm 0.52^{b}$ & $9.02 \pm 1.08^{\mathrm{a}}$ & $8.65 \pm 1.15^{\mathrm{a}}$ & $52.39 \pm 5.13^{\mathrm{a}}$ \\
\hline \multicolumn{8}{|c|}{ Enzymes, Emulsifier with Gums } \\
\hline $\begin{array}{l}\text { Xanthan (Medium)+ } \\
\text { Conventional (Medium)+ } \\
\text { Monoglyceride (Medium) }\end{array}$ & $8.67 \pm 1.15^{\mathrm{d}}$ & $8.67 \pm 1.15^{\mathrm{e}}$ & $9.00 \pm 1.00^{\mathrm{c}}$ & $8.00 \pm 0.09^{d}$ & $9.00 \pm 1.00^{\mathrm{d}}$ & $9.00 \pm 1.00^{\mathrm{d}}$ & $52.33 \pm 3.13^{\mathrm{e}}$ \\
\hline $\begin{array}{l}\text { Xanthan (Medium)+ Fungi } \\
\text { (Medium)+ Monoglyceride } \\
\text { (Medium) }\end{array}$ & $9.33 \pm 1.15^{\mathrm{b}}$ & $9.33 \pm 1.15^{b}$ & $9.97 \pm 0.06^{\mathrm{a}}$ & $9.93 \pm 0.12^{\mathrm{a}}$ & $10.00 \pm 0.00^{\mathrm{a}}$ & $9.83 \pm 0.29^{\mathrm{a}}$ & $58.40 \pm 2.08^{\mathrm{b}}$ \\
\hline $\begin{array}{l}\text { Xanthan (Medium)+ Maltogenic } \\
\text { (Medium)+ Monoglyceride } \\
\text { (Medium) }\end{array}$ & $9.50 \pm 1.00^{\mathrm{a}}$ & $9.50 \pm 1.00^{\mathrm{a}}$ & $9.98 \pm 0.05^{\mathrm{a}}$ & $9.95 \pm 0.10^{\mathrm{a}}$ & $10.00 \pm 0.00^{\mathrm{a}}$ & $9.63 \pm 0.48^{\mathrm{b}}$ & $58.55 \pm 1.73^{\mathrm{a}}$ \\
\hline $\begin{array}{l}\text { Guar Gum (Medium)+ } \\
\text { Conventional (Medium)+ } \\
\text { Monoglyceride (Medium) }\end{array}$ & $8.50 \pm 1.29^{\mathrm{e}}$ & $8.75 \pm 0.96^{\mathrm{d}}$ & $8.75 \pm 0.90^{\mathrm{d}}$ & $8.50 \pm 1.29^{\mathrm{c}}$ & $9.25 \pm 0.86^{\mathrm{c}}$ & $9.00 \pm 1.15^{\mathrm{d}}$ & $52.75 \pm 3.91^{\mathrm{d}}$ \\
\hline $\begin{array}{l}\text { Guar Gum (Medium)+ Fungi } \\
\text { (Medium) + Monoglyceride } \\
\text { (Medium) }\end{array}$ & $8.75 \pm 0.90^{\mathrm{c}}$ & $9.20 \pm 0.92^{\mathrm{c}}$ & $9.40 \pm 0.84^{\mathrm{b}}$ & $9.17 \pm 01.01^{\mathrm{b}}$ & $9.70 \pm 0.67^{\mathrm{b}}$ & $9.10 \pm 0.99^{c}$ & $55.32 \pm 2.31^{\mathrm{c}}$ \\
\hline $\begin{array}{l}\text { Guar Gum (Medium)+ } \\
\text { Maltogenic (Medium)+ } \\
\text { Monoglyceride (Medium) } \\
\end{array}$ & $8.55 \pm 1.25^{\mathrm{e}}$ & $8.70 \pm 0.90^{\mathrm{d}}$ & $8.70 \pm 0.80^{\mathrm{d}}$ & $8.53 \pm 1.23^{\mathrm{c}}$ & $9.20 \pm 0.80^{\mathrm{c}}$ & $9.05 \pm 1.10^{\mathrm{d}}$ & $52.73 \pm 3.95^{\mathrm{d}}$ \\
\hline
\end{tabular}




\section{Conclusion}

Generally, bread containing a mixture of xanthan, maltogenic $\alpha$-amylase and monoglyceride maintained superior texture characteristics over the storage period while mixture of guar, maltogenic $\alpha$ amylase and monoglyceride was less effective over the same period.

The maltogenic and fungi $\alpha$-amylase turned out to be an ideal anti-staling enzyme in bread. It showed clear anti-firming effects and was able to maintain the elastic recovery levels, which can be ascribed partly to its intermediate thermal stability.

\section{References}

AACC., 2000. Approved Methods of the American Association of Cereal Chemists, $10^{\text {th }}$ ed., St. Paul. Minnesota: The Amer. Assoc. Cereal Chem. Inc., USA.

AACC., 2010. Approved methods of the American Association of Cereal Chemists (11 ${ }^{\text {th }}$ ed.). St. Paul: Approved Methods Committee.

Abd-El-Khalek, M.H., T.A. Mohamed Amer, and M.S. Ibrahim, 2019. Determination of the staling rate of Egyptian Balady bread by using Texture Profile Analysis (TPA): A new method. Arab Universities Journal of Agricultural Sciences, 27(5): 2527-2538.

Ai, J., T. Witt, G. Cowin, S. Dhital, M.S. Turner, J.R. Stokes, and M.J. Gidley, 2018. Anti-staling of high-moisture starchy food: Effect of hydrocolloids, emulsifiers and enzymes on mechanics of steamed-rice cakes. Food Hydrocolloids, 83, 454-464.

Aleid, S.M., A.A. Al-Hulaibi, M.A. Ghoush, and A.A. Al-Shathri, 2015. Enhancing arabic bread quality and shelf-life stability using bread improvers. Journal of food science and technology, 52(8): 47614772.

Al-Eid, S.M., 2000. Behavior of Some Bread Improvers in Arabic Bread: White Pan Bread and Frankfurter Rolls. J. Agri. Univ. Khartoum, 8:118-132.

Al-Mahsaneh M., M. Aljarrah, T. Rababah and M. Alu'datt, 2018. Using of MR_FTIR and texture profile to track the effect of storage time and temperature on pita bread staling. J. Food Quality (Hindawi). (1): 1-9.

AOAC, 2002. Official methods of analysis.Association of Official Analytical Chemists $16^{\text {th }}$, Washington, DC.

Arozarena, I., H. Bertholo, J. Empis, A. Bunger, and I. Sousa, 2001. Study of the total replacement of egg by white lupine protein, emulsifiers and xanthan gum in yellow cakes. Eur. Food Res. Technol. 213(4): $312-316$

Azanza, M.P.V., E.E.C. Estilo, and F.S. Gabriel, 2016. Stalling Control in Philiphine Yeast Bread (Pandesal) Using Hydrocolloids and Emulsifiers. Philippine Journal of Science, 145(1): 25-35.

Azizi, M.H., N. Rajabzadeh, and E. Riahi, 2003. Effect of monodiglyceride and lecithin on dough rheological characteristics and quality of flat bread. Lebensm.-Wiss. Technol. 36: 189-143.

Benejam, W., M.E. Steffolani, and A.E. León, 2009. Use of enzyme to improve the technological quality of a panettone like baked product. International Journal of Food Science and Technology, 44: 2431-2437.

Crowley, P., T.J. Schober, C.I. Clarke, and E.K. Arendt, 2002. The effect of storage time on textural and crumb grain characteristics of sourdough wheat bread. European Food Research and Technology, 214(6): 489-496.

Gavilighi, H.A., M.H. Azizi, M. Barzegar, and M.A. Ameri, 2006. Effect of selected hydrocolloids on bread staling as evaluated by DSC and XRD. Journal of Food Technology, 4(3): 185-188.

Ghodke, S.K. and L. Ananthanarayan, 2007. Influence of additives on rheological characteristics of whole-wheat dough and quality of chapatti (Indian unleavened flat bread) part I - hydrocolloids. Food Hydrocolloids, 21: 110-117.

Gocmen, D., A.N. Inkaya, and E. Aydin, 2009. Flat breads. Bulgarian Journal of Agricultural Science, 15(4): 298-306.

Gray, J.A., and J.N. Bemiller, 2003. Bread staling: molecular basis and control. Comprehensive reviews in food science and food safety, 2(1): 1-21.

Guarda, A., C.M. Rosell, C. Benedito, and M.J. Galotto, 2004. Different hydrocolloids as bread improvers and anti-staling agents. Food Hydrocolloids, 18: 241-247. 
Hug-Iten, S., F. Escher, and B. Conde-Petit, 2003. Staling of bread: Role of amylose and amylopectin and influence of starch-degrading enzymes. Cereal Chemistry, 80(6): 654-661.

Kaltsa, O., T. Georgopoulos, S. Yanniotis, and I. Mandala, 2013. Effect of enzyme blends and dough strengthening emulsifier on extending the shelf life of sandwich bread applying response surface methodology. IJEIT, 3: 149-160.

Kohajdovaz, Z., J. Karovicova, and S. Schmidt, 2009. Significance of emulsifiers and hydrocolloids in bakery industry. ActaChimicaSlovaca, 2(1):46-61.

Koocheki A., S.A. Mortazavi, M.N. Mahalati, and M. Karimi, 2009. Effect of emulsifiers and fungal aamylase on rheological characteristics of wheat dough and quality of flat bread. J. Food Proc. Eng., 32: 187-205.

Kotancilar, H.G., K.E. Gerçekaslan, and M.M. Karaoğlu, 2008. Effects of loaf weight and storage time on the qualitative properties of white and traditional Vakfikebir breads. Turkish Journal of Agriculture and Forestry, 32(5): 459-467.

Larmond, E., 1982. Laboratory methods of sensory evaluation of food. Research branch. Canada Department of Agriculture Publications.

Lee, M.H.; M.H. Baek,; D.S.H.J. Cha Park, and S.T. Lim, 2002. Freeze-thaw stabilization of sweet potato starch gel by polysaccharide gums. Food Hydrocoll., 16: 345-352.

Lent, P.J. and L.A. Grant, 2001. Effects of additives and storage temperature on staling properties of breads. Cereal Chem. 78: 619-624.

Nielsen, S., 2010. Food Analysis $4^{\text {th }}$ Edition, Springer, New York.

Pahwa, A., A. Kaur, and R. Puri, 2016. Influence of hydrocolloids on the quality of major flat breads: A review. Journal of Food Processing, (1), Article ID 8750258, 9 pages.

Palacios, H.R., P.B. Schwarz, and B.L. D'Appolonia, 2004. Effects of alpha-amylases from different sources on the firming of concentrated wheat starch gels: Relationship to Bread Staling. Journal of Agricultural Food Chemistry, 52(19):5987-5994.

Patil, S., S.K. Sonawane, and S.S. Arya, 2019. A Fuzzy Mathematical Approach for Selection of Surface Coating and Its Effect on Staling Kinetics in a Formulated Gluten-Free Flatbread. Food and Bioprocess Technology, 12(11): 1955-1965.

Patil, S.P. and S.S. Arya, 2016. Influence of additives on dough rheology and quality of Thepla: an Indian unleavened flatbread. J. Food Meas. Charact. 10(2): 327-335.

Rojas, J.A., C.M. Rosell, and C. Benedito de Barber, 2001. Role of maltodextrins in the staling of starch gels Eur. Food Res. Technol, 212:364-368.

Rosell, C.M., J.A. Rojas, D.E. Benedito, C. Barber, 2001. Influence of Hydrocolloids on Dough Rheology and Bread Quality. Food Hydrocoll., 15:75-81.

Salehi, F., 2020. Effect of common and new gums on the quality, physical, and textural properties of bakery products: A review. Journal of texture studies, 51(2):.361-370.

Salehi, F., and M. Kashaninejad, 2014. Kinetics and thermodynamics of gum extraction from wild sage seed. International Journal of Food Engineering, 10(4): 625-632.

Salehi, F., M. Kashaninejad, and V. Behshad, 2014. Effect of sugars and salts on rheological properties of Balangu seed (Lallemantia royleana) gum. International Journal of Biological Macromolecules, 67:16-21.

Sidhu, J.S., J. Al-Saqer, and S. Al-Zenki, 1997. Comparison of methods for the assessment of the extent of staling in bread. Food Chemistry, 58(1-2): 161-168.

SPSS, 2000. Statistical package for Social Sciences. SPSS for Windows, Version 16, SPSS Inc., Chicago, IL, USA.

Steel, R.C. and J.H. Torrie, 1980. Principles and procedures statistics. McGraw Hill Book Company Inc. New York.

Tang, M.C. and L. Copeland, 2007. Analysis of complexes between lipids and wheat starch. Carbohydrate Polymers, 67(1): 80-85.

Tebben, L., Y. Shen, and Y. Li, 2018. Improvers and functional ingredients in whole wheat bread: A review of their effects on dough properties and bread quality. Trends in Food Science \& Technology, 81: 10-24.

Zobel, H.F. and F.R. Senti, 1959. The bread staling problem. X-ray diffraction studies on breads containing a cross-linked starch and heat-stable a-amylase. Cereal Chem., 36:441. 